\title{
Small intestinal alterations in severely obese hyperglycemic subjects
}

Citation for published version (APA):

Verdam, F. J., Greve, J. W., Roosta, S., van Eijk, H. M. H., Bouvy, N. D., Buurman, W. A., \& Rensen, S. S. M. (2011). Small intestinal alterations in severely obese hyperglycemic subjects. Journal of Clinical Endocrinology \& Metabolism, 96(2), E379-E383. https://doi.org/10.1210/jc.2010-1333

Document status and date:

Published: 01/02/2011

DOI:

10.1210/jc.2010-1333

Document Version:

Publisher's PDF, also known as Version of record

Document license:

Taverne

Please check the document version of this publication:

- A submitted manuscript is the version of the article upon submission and before peer-review. There can be important differences between the submitted version and the official published version of record.

People interested in the research are advised to contact the author for the final version of the publication, or visit the DOI to the publisher's website.

- The final author version and the galley proof are versions of the publication after peer review.

- The final published version features the final layout of the paper including the volume, issue and page numbers.

Link to publication

\footnotetext{
General rights rights.

- You may freely distribute the URL identifying the publication in the public portal. please follow below link for the End User Agreement:

www.umlib.nl/taverne-license

Take down policy

If you believe that this document breaches copyright please contact us at:

repository@maastrichtuniversity.nl

providing details and we will investigate your claim.
}

Copyright and moral rights for the publications made accessible in the public portal are retained by the authors and/or other copyright owners and it is a condition of accessing publications that users recognise and abide by the legal requirements associated with these

- Users may download and print one copy of any publication from the public portal for the purpose of private study or research.

- You may not further distribute the material or use it for any profit-making activity or commercial gain

If the publication is distributed under the terms of Article $25 \mathrm{fa}$ of the Dutch Copyright Act, indicated by the "Taverne" license above, 
Brief Report-Endocrine Research

\section{Small Intestinal Alterations in Severely Obese Hyperglycemic Subjects}

Froukje J. Verdam, Jan Willem M. Greve, Sedigheh Roosta, Hans van Eijk, Nicole Bouvy, Wim A. Buurman, and Sander S. Rensen

Department of General Surgery, School for Nutrition, Toxicology, and Metabolism Research Institute Maastricht, Maastricht University Medical Center, 6200 MD Maastricht, The Netherlands

Context: Type 2 diabetes mellitus (DM2) is associated with small intestinal hyperplasia and hypertrophy in rodents. Moreover, the small intestine is increasingly acknowledged to play a role in the pathophysiology of DM2.

Objective: The objective of the study was to investigate the relation between plasma markers of small intestinal function and chronic hyperglycemia in man.

Design, Setting, and Participants: We conducted a cross-sectional observational study of 40 severely obese subjects with chronic hyperglycemia and 30 severely obese subjects without chronic hyperglycemia who were indicated for bariatric surgery.

Main Outcome Measures: We assessed plasma levels of citrulline, representing small intestinal enterocyte mass, intestinal fatty acid binding protein (I-FABP), a marker of enterocyte loss, and glucagon-like peptide-2, an intestinotrophic factor, and related them to glycated hemoglobin $\left(\mathrm{HbA}_{1 \mathrm{c}}\right)$ levels.

Results: Plasma citrulline and I-FABP levels were both significantly elevated in subjects with chronic hyperglycemia $\left(\mathrm{HbA}_{1 \mathrm{c}}>6.0 \%\right)$ compared with subjects with a normal $\mathrm{HbA}_{1 \mathrm{c}}(\leq 6.0 \%)$ (citrulline, $35 \pm 2.1 \mu \mathrm{M}$ vs. $26 \pm 1.4 \mu \mathrm{M}, P=0.001 ; \mathrm{I}-\mathrm{FABP}, 140 \pm 22 \mathrm{pg} / \mathrm{ml} v \mathrm{~s} .69 \pm 14 \mathrm{pg} / \mathrm{ml}, P=0.001)$. Moreover, plasma citrulline and I-FABP levels correlated with $\mathrm{HbA}_{1 c}$ levels (citrulline, $\mathrm{r}_{\mathrm{s}}=0.30, P=0.02 ; \mathrm{I}-\mathrm{FABP}$, $\left.r_{\mathrm{s}}=0.33, P=0.005\right)$. The I-FABP to citrulline ratio was higher in subjects with an elevated $\mathrm{HbA}_{1 \mathrm{c}}$ (4.0 vs. 3.1, $P=0.03$ ). Plasma glucagon-like peptide-2 levels were not related to citrulline or I-FABP levels $\left(r_{\mathrm{s}}=0.06, P=0.67 ; r_{\mathrm{s}} 0.08, P=0.54\right.$, respectively).

Conclusion: Chronically elevated glucose levels in obese individuals are associated with increased small intestinal enterocyte mass and increased enterocyte loss. These findings argue for the further exploration of the role of the intestine in the pathophysiology of DM2. (J Clin Endocrinol Metab 96: E379-E383, 2011)

$\mathbf{T}^{\prime}$ ype 2 diabetes mellitus (DM2) affects more than 285 million people worldwide, a number rapidly increasing in this era of obesity (1). Traditionally, studies on the pathogenesis of DM2 have mainly focused on insulin sensitivity of liver, muscle, and adipose tissue. However, there is increasing evidence for an important role of the small intestine in the control of glucose homeostasis and in the pathogenesis of DM2. For example, the release of various

ISSN Print 0021-972X ISSN Online 1945-7197

Printed in U.S.A.

Copyright (C) 2011 by The Endocrine Society

doi: 10.1210/jc.2010-1333 Received June 11, 2010. Accepted October 15, 2010

First Published Online November 17, 2010 small intestinal peptides that control glucose homeostasis, such as glucose-dependent insulinotropic polypeptide and glucagon-like peptide-1, is disturbed in subjects with DM2 (2). In addition, gluconeogenesis in the small intestine was recently shown to regulate hepatic glucose metabolism and to contribute to the rapid beneficial effects of Roux-en-Y gastric bypass surgery on DM2 in mice (3). Importantly, bypassing the proximal intestine is associ-

Abbreviations: DM2, type 2 diabetes; GLP-2, glucagon-like peptide-2; $\mathrm{HbA}_{1 \mathrm{c}}$, glycated hemoglobin; I-FABP, intestinal fatty acid binding protein. 
ated with a rapid resolution of DM2 in man (4), supporting an important role for intestinal factors in the regulation of glucose homeostasis.

Interestingly, animals with DM2 display alterations of the small intestine such as generalized small intestinal hyperplasia and mucosal hypertrophy (5). More specifically, elevated glycated hemoglobin $\left(\mathrm{HbA}_{1 \mathrm{c}}\right)$, an indicator of chronic hyperglycemia, was found to coincide with longer intestinal villi and increased intestinal proliferation in rats with DM2. Besides morphological changes, functional alterations such as increased activity of disaccharidases and enhanced nutrient absorption were reported. Importantly, the combination of small intestinal hyperplasia and increased disaccharidase activity may contribute to the postprandial hyperglycemia that characterizes DM2.

To investigate whether chronic hyperglycemia in man is associated with similar intestinal alterations as previously described in animal models, we determined the plasma levels of citrulline, intestinal fatty acid-binding protein (I-FABP), and glucagon-like peptide-2 (GLP-2), parameters indicating intestinal mass, enterocyte loss, and enterocyte proliferation (6-8), in a population of severely obese patients with and without chronic hyperglycemia. Our results indicate that chronic hyperglycemia is associated with a higher intestinal mass and increased enterocyte loss, supporting a role for the intestine in the pathophysiology of DM2 in man.

\section{Subjects and Methods}

\section{Subjects}

From June 2006 to November 2008, 70 severely obese subjects indicated for bariatric surgery were sequentially included at the Department of General Surgery of the Maastricht University Medical Center. Patient characteristics are summarized in Table 1. Patients with type 1 diabetes, other acute or chronic inflammatory diseases (e.g. M. Crohn, colitis, hepatitis, autoimmune diseases) and patients using antiinflammatory drugs and/or reported alcohol consumption (more than $10 \mathrm{~g} / \mathrm{d}$ ) were excluded from the study. All severely obese subjects were screened for diabetes and used appropriate medication for their diabetic status. Eleven subjects used metformin, five subjects used insulin, 11 patients were treated for hyperlipidemia, and 31 subjects used antihypertensive medication. Subjects did not follow a specific diet and were not under dietary counseling at the time of sampling. This study was approved by the Medical Ethical Board of the Maastricht University Medical Center in line with the ethical guidelines of the revised version of the Declaration of Helsinki (October 2008, Seoul), and informed consent in writing was obtained from each subject.

\section{Blood sampling}

Venous blood samples were obtained after a minimum of $8 \mathrm{~h}$ fasting before bariatric surgery. All samples were collected in prechilled EDTA tubes and centrifuged at $4 \mathrm{C}$ for $10 \mathrm{~min}$ at $2000 \times g$. The plasma was centrifuged again for $10 \mathrm{~min}$ at $3500 \times g$ and stored in aliquots at $-80 \mathrm{C}$ until analysis.

\section{Biopsy sampling and quantitative PCR}

Small intestinal biopsies were obtained from all patients undergoing gastric bypass surgery $(\mathrm{n}=22)$. Biopsies were immediately snap frozen. Total RNA was isolated from $50 \mathrm{mg}$ tissue by homogenization in Tri reagent (Sigma, St. Louis, MO) according to the manufacturer's instructions. RNA (750 ng) was converted to cDNA using the iScript cDNA synthesis kit (Bio-Rad, Hercules, CA). Quantitative PCR was performed with the ABsolute SYBR Green master mix (ABgene, Leusden, The Netherlands), and the iQ5 iCycler (Bio-Rad) using the following primers: I-FABP forward, 5'-TAGCAGACGGAACTGAACTC-3', I-FABP reverse, 5'-CATAAGTCTGGACTAGTTCATCAC-3'; $\beta_{2}$-microglobulin forward, 5'-TCCATCCGACATTGAAGTTG-3', $\beta_{2}$-microglobulin reverse, 5'-CGGCAGGCATACTCATCTT-3'. Relative IFABP expression was assessed in duplicate by the $\Delta$ cycle threshold method after normalization for $\beta_{2}$-microglobulin expression.

\section{Measurements}

$\mathrm{HbA}_{1 \mathrm{c}}$ levels were measured at the Department of Clinical Chemistry according to the protocol of the University Medical Center. Citrulline levels were measured as previously described (9). Plasma I-FABP levels were determined with an ELISA according to the manufacturer's instructions (Hycult Biotech, Uden, The Netherlands). Samples were analyzed in the same run, and the interassay and intraassay coefficients of variation were less than $10 \%$. The detection limit was $40 \mathrm{pg} / \mathrm{ml}$. Plasma GLP-2 levels were determined with an ELISA according to the manufacturer's instructions (Biovendor, Modrice, Czech Republic). Samples were analyzed in two runs, and the intra- and interassay coefficient variation was less than $15 \%$.

TABLE 1. Patient characteristics

\begin{tabular}{|c|c|c|c|}
\hline & $\mathrm{HbA}_{1 \mathrm{c}} \leq 6.0$ (SEM) & $\mathrm{HbA}_{1 \mathrm{c}}>6.0$ (SEM) & $P$ value \\
\hline Number of patients & 30 & 40 & \\
\hline Sex (male:female) & $8: 22$ & $12: 28$ & 0.76 \\
\hline Age $(y r)$ & $42(1.4)$ & $48(1.3)$ & $<0.01$ \\
\hline $\mathrm{HbA}_{1 \mathrm{c}}(\%)$ & $5.7(0.1)$ & $7.3(0.2)$ & $<0.01$ \\
\hline Citrulline ( $\mu \mathrm{mol} /$ liter) & $26(1.4)$ & $35(2.1)$ & $<0.01$ \\
\hline I-FABP $(\mathrm{pg} / \mathrm{ml})$ & $69(14)$ & $140(22)$ & $<0.01$ \\
\hline Citrulline to I-FABP ratio & $3.1(0.7)$ & $4.0(0.6)$ & 0.03 \\
\hline GLP-2 (ng/ml) & $14(1.6)$ & $18(2.1)$ & 0.29 \\
\hline
\end{tabular}




\section{Statistical analysis}

Statistical analysis was performed using Prism 5.0 for Windows (GraphPad Software Inc., San Diego, CA). Data are presented as mean \pm SEM. Correlations were calculated using Spearman's rank correlation coefficient. Differences between groups were analyzed by the Mann-Whitney test or the $\chi^{2}$ test. A $P<$ 0.05 was considered statistically significant.

\section{Results}

\section{Increased plasma citrulline levels in subjects with elevated $\mathrm{HbA}_{1 \mathrm{c}}$}

The functional small intestinal mass has previously been shown to be accurately reflected by plasma levels of citrulline, an amino acid that is not incorporated into proteins, and produced by differentiated small intestinal enterocytes from glutamine (6). Therefore, to study the relation between small intestinal mass and hyperglycemia, we first assessed citrulline plasma levels of 30 severely obese subjects with $\mathrm{HbA}_{1 \mathrm{c}}$ of $6.0 \%$ or less [the upper limit of normal (10)] and 40 severely obese subjects with $\mathrm{HbA}_{1 \mathrm{c}}$ greater than $6.0 \%$. In the total population, plasma citrulline levels ranged from 13 to $78 \mu \mathrm{M}$, with a mean of $31 \pm$ $1.4 \mu \mathrm{M}$, and a median of $30 \mu \mathrm{M}$. Interestingly, plasma citrulline levels were significantly higher in patients with an elevated $\mathrm{HbA}_{1 \mathrm{c}}\left(\mathrm{HbA}_{1 \mathrm{c}}>6.0: 35 \pm 2.1 \mu \mathrm{M} v s . \mathrm{HbA}_{1 \mathrm{c}} \leq 6.0\right.$ : $26 \pm 1.4 \mu \mathrm{M}, P=0.001$, Fig. 1A). Furthermore, citrulline levels correlated with $\mathrm{HbA}_{1 \mathrm{c}}$ levels $\left(\mathrm{r}_{\mathrm{s}}=0.30, P=0.02\right.$, Supplemental Fig. 1A, published on The Endocrine Society's Journals Online web site at http://jcem.endojournals.org). These data indicate that severely obese patients with chronic hyperglycemia have an increased functional small intestinal enterocyte mass.

\section{High $\mathrm{HbA}_{1 \mathrm{c}}$ is associated with increased plasma I-FABP in severely obese subjects}

To obtain additional evidence for the increased small bowel mass in subjects with chronic hyperglycemia, we next investigated small intestinal enterocyte turnover by measuring plasma I-FABP levels. I-FABP is a gut-associated cytosolic carrier protein involved in the intracellular buffering and transport of fatty acids, which plasma levels have been shown to indicate small intestinal enterocyte loss $(8,11)$. Assuming steady state, circulating levels of I-FABP also represent the production of enterocytes, or in other words enterocyte turnover. Like citrulline, plasma I-FABP levels were significantly higher in severely obese patients with an elevated $\mathrm{HbA}_{1 \mathrm{c}}\left(\mathrm{HbA}_{1 \mathrm{c}}>6.0: 140 \pm 22\right.$ $\mathrm{pg} / \mathrm{ml} v s . \mathrm{HbA}_{1 \mathrm{c}} \leq 6.0: 69 \pm 14 \mathrm{pg} / \mathrm{ml}, P=0.001$, Fig. $\left.1 \mathrm{~B}\right)$. Importantly, quantitative PCR analysis showed that there was no difference in relative I-FABP expression between subjects with and without chronic hyperglycemia $(0.63 \pm$
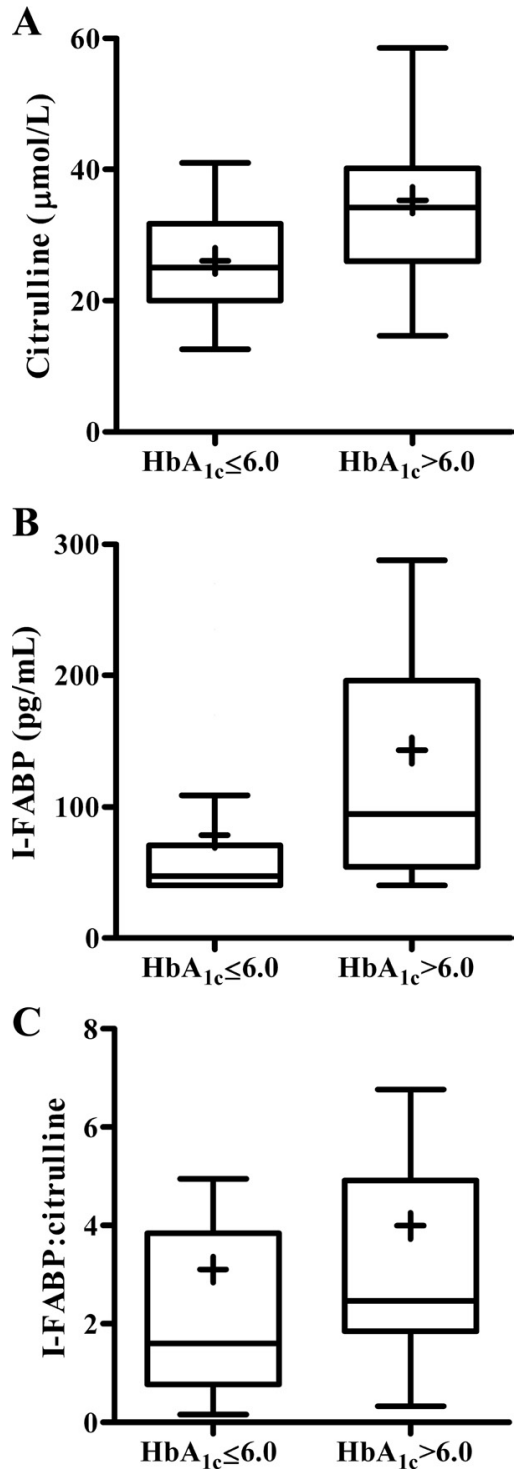

FIG. 1. Increased levels of plasma parameters reflecting enterocyte mass and enterocyte loss in severely obese subjects with chronic hyperglycemia. A, Tukey box and whiskers plot showing that severely obese subjects with an elevated $\mathrm{HbA}_{1 \mathrm{c}}(>6.0)$ display significantly increased plasma levels of citrulline as compared with severely obese subjects with a normal $\mathrm{HbA}_{1 \mathrm{c}}(\leq 6.0)(P=0.001)$. The horizontal line corresponds with the mean, whereas the outer boxes represent the 25 th and the 75 th percentiles. Whiskers show the nonoutlier range. A value was defined as an outlier if it was more than 1.5 times the box height above or below the box. The + symbol indicates the mean value. $B$, Plasma I-FABP levels of severely obese subjects with an $\mathrm{HbA}_{1 \mathrm{c}}>6.0$ are significantly higher in comparison with I-FABP levels of severely obese subjects with a normal $\mathrm{HbA}_{1 \mathrm{C}}(P=0.001)$. C, Significantly higher I-FABP to citrulline ratio in severely obese subjects with $\mathrm{HbA}_{1 c}$ greater than 6.0 as compared with severely obese subjects with a normal $\mathrm{HbA}_{1 c}(P=0.03)$.

0.09 vs. $0.60 \pm 0.14, P=0.55$, Supplemental Fig. 2 ). This indicates that the increased plasma I-FABP levels in subjects with elevated $\mathrm{HbA}_{1 \mathrm{c}}$ cannot be attributed to increased expression of I-FABP. Furthermore, I-FABP levels also significantly correlated with $\mathrm{HbA}_{1 \mathrm{c}}\left(\mathrm{r}_{\mathrm{s}}=0.33, P=\right.$ $0.005)$. Circulating plasma I-FABP levels showed a significant positive correlation to plasma citrulline levels as well 
$\left(\mathrm{r}_{\mathrm{s}}=0.26, P=0.03\right.$, Supplemental Fig. 1B). Taken together, these data suggest an increased enterocyte turnover in severely obese patients with an elevated $\mathrm{HbA}_{1 \mathrm{c}}$.

\section{Plasma I-FABP to citrulline ratio indicates disproportionally increased enterocyte loss in subjects with elevated $\mathrm{HbA}_{1 c}$}

To further explore the relation between enterocyte mass, enterocyte loss, and enterocyte turnover, we calculated the ratio of plasma values of I-FABP and citrulline for every subject. The I-FABP to citrulline ratio correlated significantly with $\mathrm{HbA}_{1 \mathrm{c}}$ levels $\left(\mathrm{r}_{\mathrm{s}}=0.30, P=0.04\right.$, Supplemental Fig. 1C). Whereas the I-FABP to citrulline ratio was 3.1 for subjects with a normal $\mathrm{HbA}_{1 \mathrm{c}}$, subjects with an $\mathrm{HbA}_{1 \mathrm{c}}$ greater than 6 displayed a significantly higher ratio of $4.0(P=0.03$, Fig. $1 C)$. This suggests that the increased enterocyte loss in chronically hyperglycemic subjects as indicated by I-FABP plasma levels cannot merely be explained by their relatively higher enterocyte mass. Moreover, the higher enterocyte mass despite the increased enterocyte loss suggests that severely obese subjects with an elevated $\mathrm{HbA}_{1 \mathrm{c}}$ have an increased enterocyte proliferation and turnover.

\section{GLP-2 plasma levels do not correlate with plasma citrulline and plasma I-FABP}

To study a potential mechanistic factor underlying the increased enterocyte mass and turnover in subjects with DM2, we next measured plasma levels of the incretin GLP-2. This peptide is a potent intestinal proliferative factor (7). However, fasting GLP-2 levels did not correlate with either plasma citrulline or I-FABP levels in the severely obese population $\left(\mathrm{r}_{\mathrm{s}}=0.06, P=0.67\right.$ and $\mathrm{r}_{\mathrm{s}}=0.08$, $P=0.54$, respectively) or the I-FABP to citrulline ratio $\left(\mathrm{r}_{\mathrm{s}}\right.$ $=0.09, P=0.50)$. On the other hand, plasma GLP-2 levels did significantly correlate with $\mathrm{HbA}_{1 \mathrm{c}}$ levels $\left(\mathrm{r}_{\mathrm{s}}=0.25\right.$, $P<0.05)$, in line with the known glucose-stimulated release of GLP-2 from L cells in the small intestine (7). These findings suggest that the increased small intestinal enterocyte mass and turnover in severely obese subjects with elevated $\mathrm{HbA}_{1 \mathrm{c}}$ are not mediated by GLP-2.

\section{Discussion}

In the present study, we obtained the first evidence that chronic hyperglycemia in man is associated with both an increased small intestinal enterocyte mass and increased enterocyte loss. The increase in small intestinal enterocyte mass is in line with findings in rat models of DM2 which show increased intestinal proliferation and longer villi (5). Moreover, streptozotocin-induced hyperglycemia was also found to be associated with small intestinal hyperplasia and hypertrophy in rats (12).

An increased small intestinal enterocyte mass can have important implications in the context of diabetes. First of all, it may account for the enhanced intestinal capacity to absorb glucose, as observed in DM2 (13). This enhanced carbohydrate absorption is likely to be involved in the postprandial hyperglycemia and elevated $\mathrm{HbA}_{1 \mathrm{c}}$ levels that characterize DM2. Moreover, a higher number of small intestinal enterocytes results in an increased potential for intestinal gluconeogenesis, a phenomenon that has been shown to contribute up to one third of the total glucose production in diabetic rats (14).

The mechanisms responsible for the higher small intestinal mass in subjects with chronic hyperglycemia remain unknown, although their relatively increased I-FABP to citrulline ratio indicates that intestinal epithelial proliferation must be augmented in these subjects. It was previously shown that hyperphagia is one of the factors promoting intestinal hyperplasia in streptozotocin-induced diabetic rats (12). However, it seems unlikely that hyperphagia is responsible for the increased intestinal proliferation observed in this study because both study groups had a similar body mass index. Nevertheless, it would be of interest to relate enterocyte mass and turnover to appetite and caloric intake in future studies.

Next to hyperphagia, enhanced secretion of the intestinotrophic peptide GLP-2 by enteroendocrine cells could be a factor driving the increased enterocyte proliferation in chronically hyperglycemic patients. However, GLP-2 levels were comparable between both study groups, indicating that the observed proliferative alterations cannot be attributed to GLP-2 either. The similar GLP-2 levels may also suggest that, in contrast to the enterocytes, enteroendocrine cells are not affected in DM2. Further studies are required to unravel potential alterations in enterocytes and enteroendocrine cells in DM2 in more detail.

Interestingly, next to the increased intestinal mass in subjects with elevated $\mathrm{HbA}_{1 \mathrm{c}}$ levels, both their small intestinal enterocyte loss, as reflected by plasma I-FABP levels, and their I-FABP to citrulline ratio were also higher. Recently it was shown that DM2 is accompanied by significant alterations in tight junction distribution and intestinal permeability in mice, thereby promoting endotoxininduced low-grade inflammation $(15,16)$. Subjects with DM2 have also been shown to display elevated plasma endotoxin levels that may be related to increased intestinal permeability (17). It is tempting to speculate that the increased enterocyte loss that we observed in subjects with chronic hyperglycemia may contribute to the impaired intestinal barrier function in DM2. However, we cannot rule out that the elevated plasma I-FABP levels in obese sub- 
jects with DM2 reflect increased expression by enterocytes rather than increased enterocyte loss. In fact, some evidence was recently reported for an association between body weight and increased I-FABP expression after small bowel resection in pigs (18).

In summary, we presented evidence for both an increased functional enterocyte mass and increased enterocyte loss and turnover in severely obese subjects with elevated $\mathrm{HbA}_{1 \mathrm{c}}$ levels. Our findings indicate for the first time significant alterations in the pathophysiology of the intestine in human obesity-induced DM2.

\section{Acknowledgments}

Address all correspondence and requests for reprints to: Dr. S. Rensen, Department of General Surgery, Maastricht University Medical Center, P.O. Box 616, 6200 MD Maastricht, The Netherlands. E-mail: s.rensen@maastrichtuniversity.nl.

This work was supported by the Senter Novem Innovation Oriented Research Program on Genomics, Grant IGE05012, and a Transnational University Limburg grant.

Current address for J.W.M.G.: Department of Surgery, Atrium Medical Center, Heerlen, The Netherlands.

Disclosure Summary: The authors have nothing to disclose.

\section{References}

1. Shaw JE, Sicree RA, Zimmet PZ 2010 Global estimates of the prevalence of diabetes for 2010 and 2030. Diabetes Res Clin Pract 87: 4-14

2. Drucker DJ 2007 The role of gut hormones in glucose homeostasis. J Clin Invest 117:24-32

3. Troy S, Soty M, Ribeiro L, Laval L, Migrenne S, Fioramonti X, Pillot B, Fauveau V, Aubert R, Viollet B, Foretz M, Leclerc J, Duchampt A, Zitoun C, Thorens B, Magnan C, Mithieux G, Andreelli F 2008 Intestinal gluconeogenesis is a key factor for early metabolic changes after gastric bypass but not after gastric lap-band in mice. Cell Metab 8:201-211

4. Rubino F, R'bibo SL, del Genio F, Mazumdar M, McGraw TE 2008 Metabolic surgery: the role of the gastrointestinal tract in diabetes mellitus. Nat Rev Endocrinol 6:102-109

5. Adachi T, Mori C, Sakurai K, Shihara N, Tsuda K, Yasuda K 2003
Morphological changes and increased sucrase and isomaltase activity in small intestines of insulin-deficient and type 2 diabetic rats. Endocr J 50:271-279

6. Crenn P, Messing B, Cynober L 2008 Citrulline as a biomarker of intestinal failure due to enterocyte mass reduction. Clin Nutr 27: $328-339$

7. Drozdowski L, Thomson AB 2009 Intestinal hormones and growth factors: effects on the small intestine. World J Gastroenterol 15: 385-406

8. Pelsers MM, Hermens WT, Glatz JF 2005 Fatty acid-binding proteins as plasma markers of tissue injury. Clin Chim Acta 352:15-35

9. van Eijk HM, van der Heijden MA, van Berlo CL, Soeters PB 1988 Fully automated liquid-chromatographic determination of amino acids. Clin Chem 34:2510-2513

10. Gillett MJ 2009 International Expert Committee Report on the Role of the A1C Assay in the Diagnosis of Diabetes: Diabetes Care 2009; 32(7):1327-1334. Clin Biochem Rev 30:197-200

11. Lieberman JM, Sacchettini J, Marks C, Marks WH 1997 Human intestinal fatty acid binding protein: report of an assay with studies in normal volunteers and intestinal ischemia. Surgery 121:335-342

12. Noda T, Iwakiri R, Fujimoto K, Yoshida T, Utsumi H, Sakata H, Hisatomi A, Aw TY 2001 Suppression of apoptosis is responsible for increased thickness of intestinal mucosa in streptozotocin-induced diabetic rats. Metabolism 50:259-264

13. Dyer J, Wood IS, Palejwala A, Ellis A, Shirazi-Beechey SP 2002 Expression of monosaccharide transporters in intestine of diabetic humans. Am J Physiol Gastrointest Liver Physiol 282:G241-G248

14. Mithieux G, Bady I, Gautier A, Croset M, Rajas F, Zitoun C 2004 Induction of control genes in intestinal gluconeogenesis is sequential during fasting and maximal in diabetes. Am J Physiol Endocrinol Metab 286:E370-E375

15. Brun P, Castagliuolo I, Di Leo V, Buda A, Pinzani M, Palù G, Martines D 2007 Increased intestinal permeability in obese mice: new evidence in the pathogenesis of nonalcoholic steatohepatitis. Am J Physiol Gastrointest Liver Physiol 292:G518-G525

16. Cani PD, Possemiers S, Van de Wiele T, Guiot Y, Everard A, Rottier O, Geurts L, Naslain D, Neyrinck AM, Lambert DM, Muccioli GG, Delzenne NM 2009 Changes in gut microbiota control inflammation in obese mice through a mechanism involving GLP-2-driven improvement of gut permeability. Gut 58:1091-1103

17. Creely SJ, McTernan PG, Kusminski CM, Fisher M, Da Silva NF, Khanolkar M, Evans M, Harte AL, Kumar S 2007 Lipopolysaccharide activates an innate immune system response in human adipose tissue in obesity and type 2 diabetes. Am J Physiol Endocrinol Metab 292:E740-E747

18. Stephens AN, Pereira-Fantini PM, Wilson G, Taylor RG, Rainczuk A, Meehan KL, Sourial M, Fuller PJ, Stanton PG, Robertson DM, Bines JE 2010 Proteomic analysis of the intestinal adaptation response reveals altered expression of fatty acid binding proteins following massive small bowel resection. J Proteome Res 9:1437-1449 